\title{
Estimate of the Wind Resource of Two Cities in the Sahara and Sahel in Chad
}

\author{
Abakar Mahamat Tahir ${ }^{1, ~}$, Mahamat Adoum Abdraman ${ }^{2}$, Ruben Mouangue ${ }^{3}$, Alexis Kuitche ${ }^{2}$ \\ ${ }^{1}$ Faculty of Exact Sciences, University of N'Djamena, N'Djamena, Chad \\ ${ }^{2}$ Department of Electrical, Energy and Automatic Engineering, University of Ngaoundéré, Ngaoundere, Cameroon \\ ${ }^{3}$ Department of Energy Engineering, University of Ngaounderé, Ngaoundere, Cameroon
}

Email address:

abakarmt@gmail.com (A. M. Tahir)

${ }^{*}$ Corresponding author

\section{To cite this article:}

Abakar Mahamat Tahir, Mahamat Adoum Abdraman, Ruben Mouangue, Alexis Kuitche. Estimate of the Wind Resource of Two Cities in the Sahara and Sahel in Chad. International Journal of Energy and Power Engineering. Vol. 9, No. 6, 2020, pp. 86-94.

doi: $10.11648 /$ j.ijepe.20200906.11

Received: October 30, 2020; Accepted: November 13, 2020; Published: December 16, 2020

\begin{abstract}
The objective of this work is to map the wind resource of two cities of Ndjamena and Faya located respectively in Chadian Sahara and Sahel. As well as the evaluation of the annual energy produced at an altitude of $80 \mathrm{~m}$ or $100 \mathrm{~m}$ by the simulation of wind data from wind speed data collected from metrological stations in the Sahara and Sahel areas respectively in the cities of Ndjamena and Faya Airport, and available for five years. In this perspective, we start with the description of the site, the determination of the various wind parameters, such as the mathematical modeling of the wind frequency distribution: Weibull distribution and the numerical simulation of the real wind data collected over five years to provide predictions on sites in two cities of Ndjamena and Faya. Then, we estimate its wind potential, its prediction of the electrical energy produced and we carry out an analysis of the wind turbulence by taking into account the obstacles surrounding near the measurement mast of Ndjamena and Faya, the topography, the roughness of the site, the density and a judicious choice of wind turbines.
\end{abstract}

Keywords: Wind, Resource, Energy, Sahara, Sahel, Simulation, Pumping, Ndjamena, Faya, Wind Power Density, Wind Frequency Distribution

\section{Introduction}

First, we will assess the wind resource at N'Djamena and Faya, two sites in the Chad province. It allows us to judge the advisability of implementing a wind project. In this part, the results of the mapping are then presented and discussed [1-3].

Description of study areas Ndjamena: capital of the Republic of Chad, located at an elevation of $297 \mathrm{~m}$ (height above the sea) in the center-west of the country, at the confluence of the Chari and Logone rivers, on the right bank of the Chari. Two bridges connect Ndjamena to the left bank of the Chari: one single-track (the Chagoua bridge), and one double-track (the Taiwan bridge). Kousseri Cameroonian town of is located about $10 \mathrm{~km}$ from Ndjamena, on the left bank of the Logone River, which marks the border and is accessible by the Ngueli Bridge. The meteorological station is located at Ndjamena airport, which geographical coordinates of the wind data measurement mast are: longitude 15 01'48.49E and latitude 12 07'36.24' 'N

Faya: It benefits from a hot desert climate markedly accentuated, typical of Borkou, a Chadian region located in the hyper-arid Saharan zone, in the heart of the largest hot desert in the world. The coolest months are December and January with maximum temperatures between $28 \mathrm{C}$ and $29 \mathrm{C}$. The sky is perfectly clear in this extremely dry region. It is one of the hottest, driest and sunniest regions in the world. The potential evaporation reaches an overall maximum: it is recorded between 6,000 and 7,000 mm per year in Faya, a power that evaporates from the air four times higher than the average annual precipitation. The weather station is located at Faya Airport, which geographical coordinates the wind data measurement mast are: longitude 17 55'05.01"E and latitude 19 06'23.75"N [4]. 


\section{SRTM Topographic Data (Shuttle Radar Topography Mission)}

The SRTM data is the result of a collaborative between NASA (National Space and Aeronautics Administration) and NGA (National Geospatial Intelligence Agency - previously known as the National Imaging and Mapping Agency, or NIMA). Together, they produced a digital terrain model of the global surface of the planet. Digital Subterranean Model (NASASRTM) at a resolution of 30 meters, and is available in free access since 2015 and this in favor of the announcement made by the White House on September 23, 2014 and Executive Order of President Obama. Today this data is available from the Jet Propulsion Laboratory (NASA) of the California Institute of Technology (www.jpl.nasa.gov/srtm/.Oct.2018) It is this fi le SRTM which will subsequently be used to model and simulate the influence of obstacles and roughness on wind speed and movement $[5,6]$.

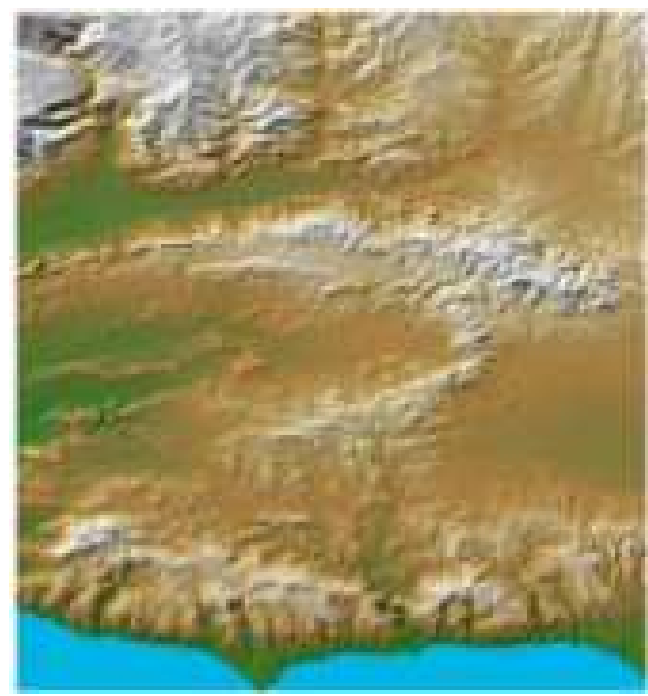

Figure 1. SRTM image of a digital elevation model [The Shuttle Radar Topography Mission (SRTM) Collection User Guide, 2015].

\section{Wind}

\subsection{Wind Rating}

Using a WAsP atlas gives an assessment of the wind at a site. The program can estimate the wind climate at any point and produce a wind atlas. By presenting descriptions of the terrain around the intended location, models can predict the actual and expected wind climate at that location [7].

\subsection{Wind Power Potential Evaluation}

The total energy content of the mean wind is calculated by WasP. In addition, an estimate of the actual average annual energy production of a turbine, one can obtain from WAsP the power curve of the wind turbine in question [8].

\subsection{Calculation of the Production of a Wind Farm}

Given the power and energy coefficient curves of the turbine, WAsP can estimate the wake losses for each turbine in a farm and thereby the net annual energy production of each turbine and the entire farm, that is ie gross production without wake losses [9].

\subsubsection{Data Used}

To estimate the wind potential available in a given region and establish the wind map there, the WAsP requires a good number of data summarized as follows:

\subsubsection{Wind Data}

The data that must be introduced in this software and which represents the first input are defined as follows:

1. Coordinates of the measurement point (Longitude and Latitude in)

2. The height of the anemometer (m)

3. Wind direction (in)

4. Wind speed (in $\mathrm{m} / \mathrm{s}$ )

The introduction of the wind speed and direction in this software must be done in the form of a file.

\subsubsection{Obstacle Data}

The second input de fines data relating to the group of obstacles present around the measuring mast. These data are characterized by their distance from the mast, the opening angle and the height of the obstacle.

\subsubsection{Topographic Data}

Because of the existence of CLA, wind speed increases with altitude. Thus, the data measured at the level of a meteorological station cannot represent the wind potential available throughout the region studied. The third input can be prepared via software by the Surfer software for input to the WAsP.

\subsubsection{Roughness Data}

It concerns all that can block, slow down or change the speed or direction of the wind for the mentioned on the WAsP software, it is necessary to take the roughness inside and outside after having delimited the zone.

\section{Modeling of the Obstacles of the Collection Site}

Some major obstacles at the Ndjamena and Faya airport site were modeled to take into account their influences on data collection. In black, we have the buildings and in blue, the trees.

\section{Wind Potential of the Airport Site up to Collection}

Wind speed measurements were grouped into intervals and associated with their frequencies on the site. This mode of representation gives us information on the number of hours for which the speeds are in a specific interval. Those for the Ndjamena and Faya airport are presented in table 1 and table 2 . 
The Weibull parameters for the two sites are given respectively: $\mathrm{C}=4.2 \mathrm{~m} / \mathrm{s} ; \mathrm{k}=1.44$ and $\mathrm{C}=1.69 \mathrm{~m} / \mathrm{s} ; \mathrm{k}=6.2$. The wind rose shows the distribution of wind attendance according to the direction on the site. It allows us to know the direction of the prevailing wind $[10,11]$. Atmospheric circulation at ground level is mainly driven by the northeast early wind for the city of Ndjamena and north-northeast for the city of Faya. The frequency analysis of wind speed highlights the predominant speed classes. Therefore, and depending on

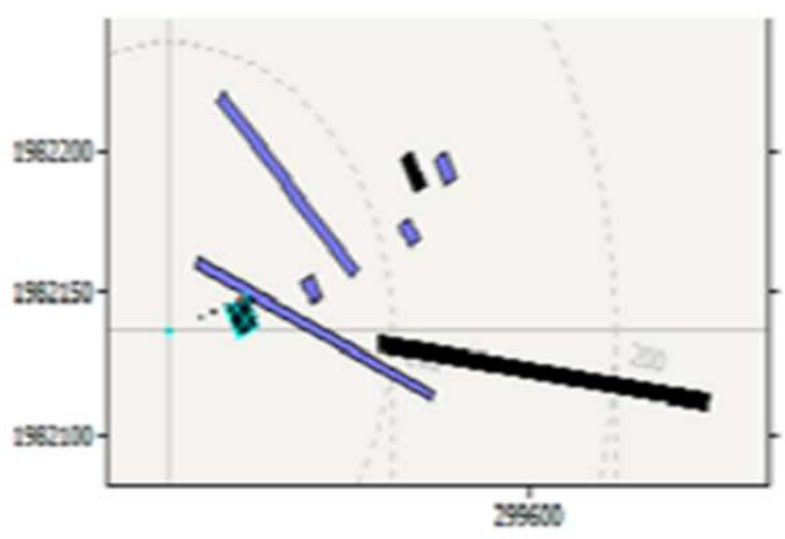

1-modeled obstacles in Ndjamena site the characteristics of the wind turbines available on the market, one can choose those that provide the best performance. We study the distribution of wind speed by class, the frequency being expressed directly (in percentage), which allows to know the probability that a speed value is not exceeded [12]. These parameters being known, it is possible to represent on the same graph the probability density function and the velocity frequency histogram.

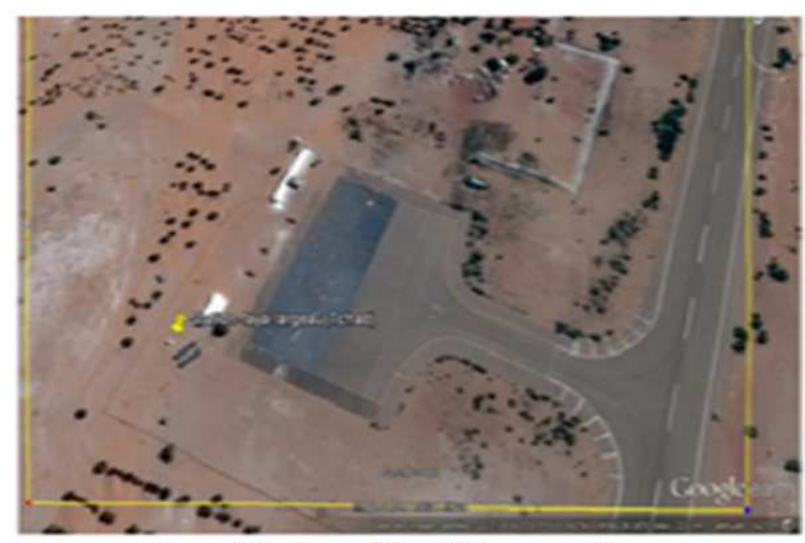

2- aerial view of the Ndjamena site

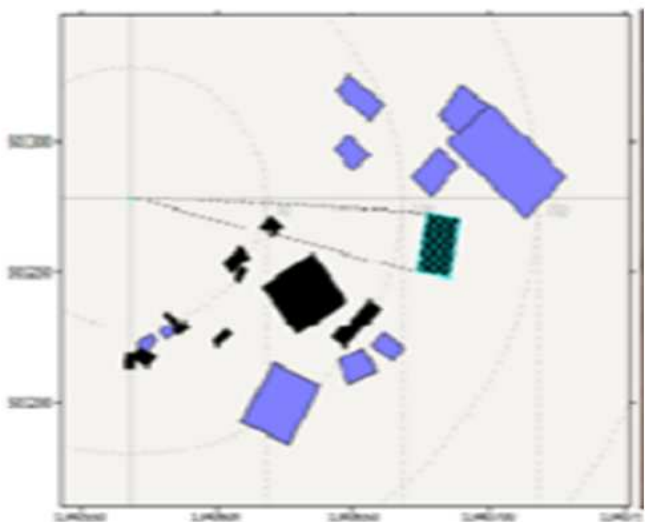

3-modeled obstacles in Faya site

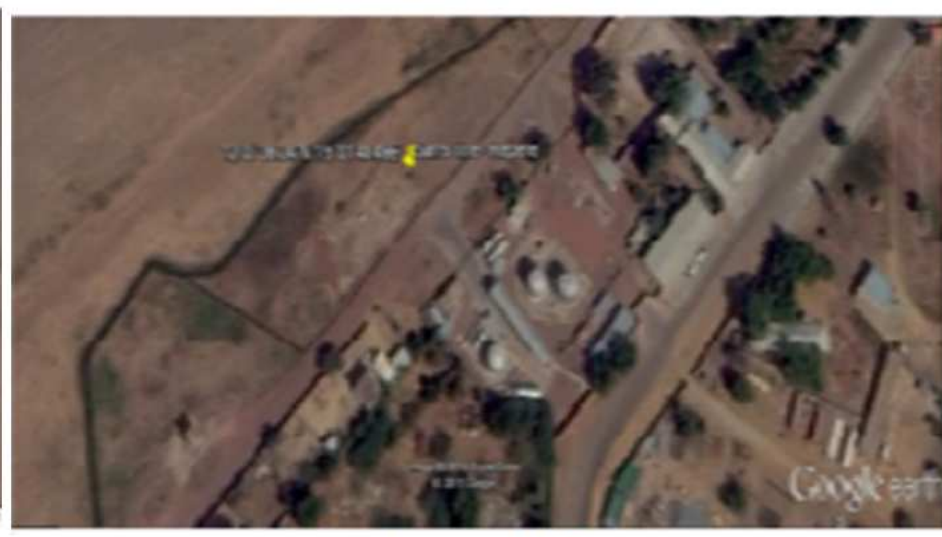

4-aerial view of the Faya site

Figure 2. Collection sites.

Table 1. Wind speed in frequency distribution format for the city of N'Djamena in $(\mathrm{m} / \mathrm{s})$.

\begin{tabular}{|c|c|c|c|c|c|c|c|c|c|c|}
\hline speed & $0-1$ & $1-2$ & $2-3$ & $3-4$ & $4-5$ & $5-6$ & $6-7$ & $7-8$ & 8-9 & $9-10$ \\
\hline $\begin{array}{l}\text { Frequencies } \\
\text { speed } \\
\text { Frequencies }\end{array}$ & $\begin{array}{l}6,7 \\
10-11 \\
0.9\end{array}$ & $\begin{array}{l}13,5 \\
11-12 \\
0.6\end{array}$ & $\begin{array}{l}21,2 \\
12-13 \\
0.6\end{array}$ & $\begin{array}{l}19,7 \\
13-14 \\
0.3\end{array}$ & $\begin{array}{l}13,1 \\
14-15 \\
0.1\end{array}$ & 9,4 & 6,3 & 3,9 & 2,4 & 1,4 \\
\hline
\end{tabular}

Table 2. Wind speed in frequency distribution format for the city of Faya in $(\mathrm{m} / \mathrm{s})$.

\begin{tabular}{llllllllll}
\hline speed & $\mathbf{0 - 1}$ & $\mathbf{1 - 2}$ & $\mathbf{2 - 3}$ & $\mathbf{3 - 4}$ & $\mathbf{4 - 5}$ & $\mathbf{5 - 6}$ & $\mathbf{6 - 7}$ & $\mathbf{7 - 8}$ & $\mathbf{8 - 9}$ \\
\hline Frequencies & 6,4 & 2,2 & 9,7 & 15,6 & 14,6 & 13 & 10,8 & 8,2 \\
speed & $10-11$ & $11-12$ & $12-13$ & $13-14$ & $14-15$ & & & & \\
Frequencies & 3,1 & 1,4 & 1,5 & 1,3 & 1,11 & & & \\
\hline
\end{tabular}

\section{Probability Density Function}

The Weibull function makes it possible to characterize the frequency distribution of wind speeds over a given period. However, for the analysis of the wind potential of a site, this distribution used for a period of one year or more $[12,16$, 19]. The distribution's equation describes the parameters of the Weibull probability density function of wind speed and follows the shape of a 1/2 "Gaussian" and are the same as those of the CDF. The blue curve represents the PDF and the black histogram represents the data. 


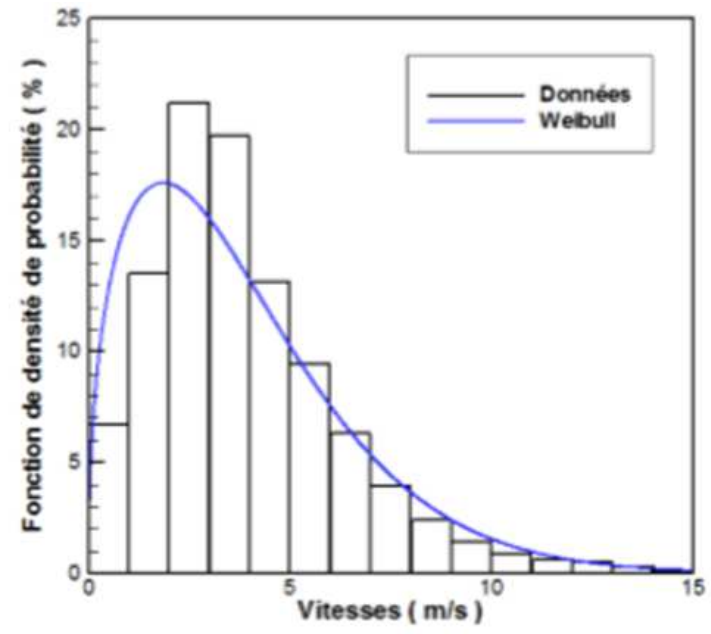

Probability density function (\%) as a function of the speed $(\mathrm{m} / \mathrm{s}$ ) of the city of Ndjamena

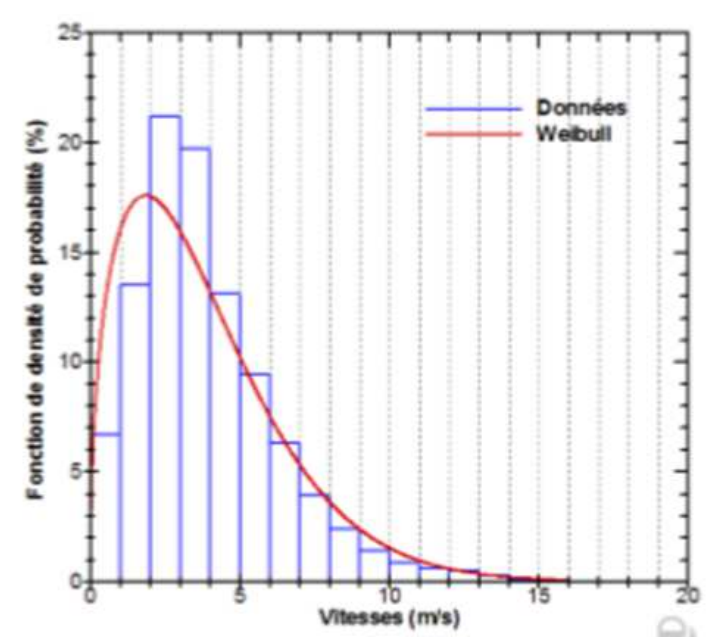

Probability density function (\%) as a function of the speed $(\mathrm{m} / \mathrm{s})$ of the city of Faya

Figure 3. Histogram of the wind speed frequencies modeled by the Weibull distribution. The calculations were carried out using a code written in FORTRAN 90 .

The Weibull probability density function was used here to predict the behavior of the wind regime at our sites.

\section{Cumulative Distribution Function}

The settings for the cumulative distribution function (CDF) of the awning are the same as those used for the PDF. The curve represents the CDF and the histogram the data. Another observation shows us a similarity between the evolution of the histogram and the shape of the CDF curve.

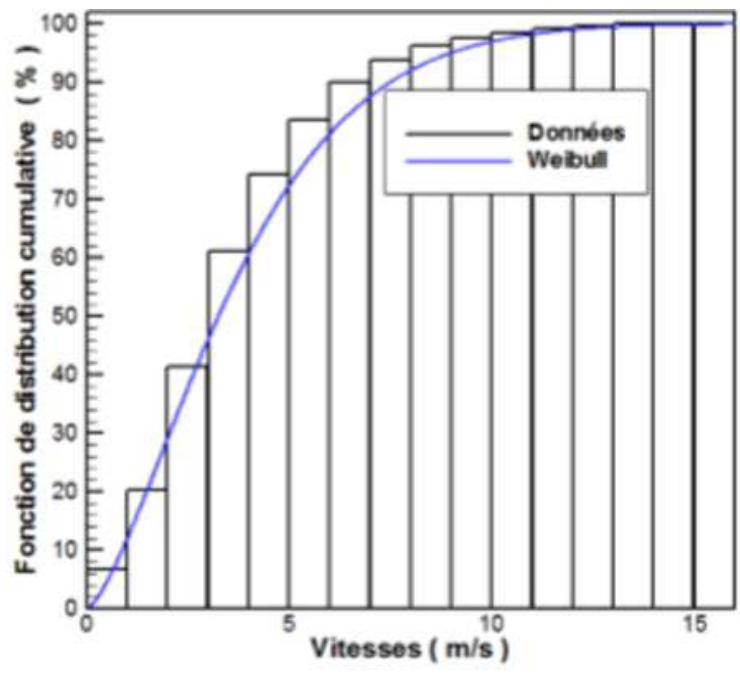

Cumulative distribution function according to speed for the city of Ndjamena

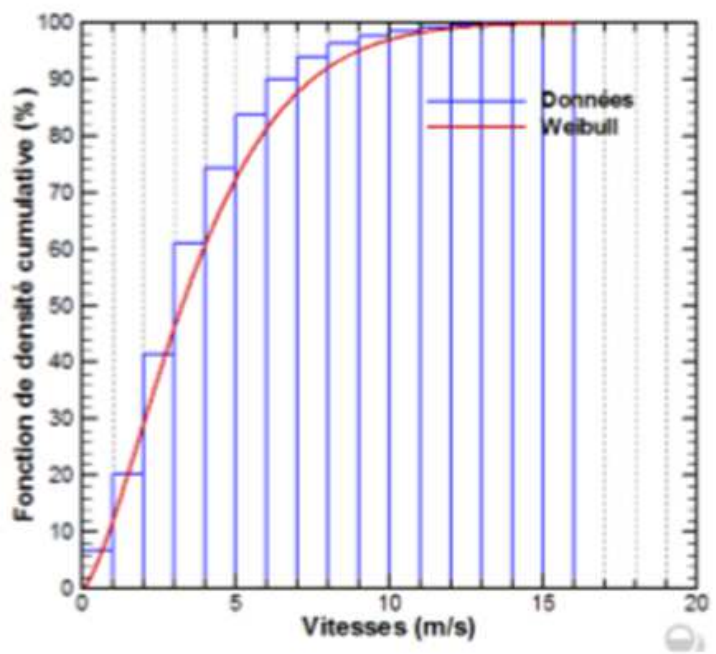

Cumulative distribution function according to speed for the city of Faya

Figure 4. Histogram of the cumulative frequencies of the wind speed modeled by the Weibull distribution. The calculations were carried out using a code written in FORTRAN 90.

Wind Atlas

The characteristics of the wind are specified for a certain number of roughness classes taken as a reference and for heights taken from ground level. These characteristics are independent of the site and therefore describe the behavior of the wind in general. 
Table 3. Wind atlas of the city of Ndjamena.

\begin{tabular}{|c|c|c|c|c|c|c|}
\hline & & $\begin{array}{l}R \text {-class } 0 \\
0.000 m\end{array}$ & $\begin{array}{l}R \text {-class } 1 \\
0.030 m\end{array}$ & $\begin{array}{l}R \text {-class } 2 \\
0.030 \mathrm{~m}\end{array}$ & $\begin{array}{l}R \text {-class } 3 \\
0.400 m\end{array}$ & $\begin{array}{l}R \text {-class } 4 \\
1.500 m\end{array}$ \\
\hline Height 1 & $\mathrm{U}(\mathrm{m} / \mathrm{s})$ & 7.40 & 5.49 & 4.80 & 3.79 & 2.52 \\
\hline$Z=10 m$ & $\mathrm{P}\left(\mathrm{W} / \mathrm{m}^{2}\right)$ & 748 & 319 & 280 & 101 & 29 \\
\hline Height 2 & $\mathrm{U}(\mathrm{m} / \mathrm{s})$ & 8,07 & 6,46 & 5,85 & 4,93 & 3,78 \\
\hline$Z=25 \mathrm{~m}$ & $\mathrm{P}\left(\mathrm{W} / \mathrm{m}^{2}\right)$ & 952 & 493 & 361 & 213 & 96 \\
\hline Height 3 & $\mathrm{U}(\mathrm{m} / \mathrm{s})$ & 8,61 & 7,31 & 6,73 & 5,87 & 4,79 \\
\hline$Z=50 m$ & $\mathrm{P}\left(\mathrm{W} / \mathrm{m}^{2}\right)$ & 1126 & 665 & 515 & 340 & 186 \\
\hline$Z=100 m$ & $\mathrm{P}\left(\mathrm{W} / \mathrm{m}^{2}\right)$ & 1363 & 898 & 725 & 515 & 320 \\
\hline Height 5 & $\mathrm{U}(\mathrm{m} / \mathrm{s})$ & 9,93 & 9,74 & 9,12 & 8,24 & 7,17 \\
\hline$Z=200 m$ & $\mathrm{P}\left(\mathrm{W} / \mathrm{m}^{2}\right)$ & 1707 & 1348 & 1100 & 811 & 542 \\
\hline
\end{tabular}

Table 4. Wind Atlas of the city of Faya.

\begin{tabular}{|c|c|c|c|c|c|c|}
\hline & & $\begin{array}{l}R \text {-class } 0 \\
0.000 m\end{array}$ & $\begin{array}{l}R \text {-class } 1 \\
0.030 m\end{array}$ & $\begin{array}{l}R \text {-class } 2 \\
0.030 m\end{array}$ & $\begin{array}{l}R \text {-class } 3 \\
0.400 m\end{array}$ & $\begin{array}{l}R \text {-class } 4 \\
1.500 \mathrm{~m}\end{array}$ \\
\hline Height 1 & $\mathrm{U}(\mathrm{m} / \mathrm{s})$ & 14,22 & 10,46 & 9,11 & 7,14 & 4,74 \\
\hline$Z=10 m$ & $\mathrm{P}\left(\mathrm{W} / \mathrm{m}^{2}\right)$ & 4415 & 1793 & 1167 & 558 & 161 \\
\hline Height 2 & $\mathrm{U}(\mathrm{m} / \mathrm{s})$ & 15,44 & 12,15 & 10,95 & 9,20 & 7,04 \\
\hline$Z=25 \mathrm{~m}$ & $\mathrm{P}\left(\mathrm{W} / \mathrm{m}^{2}\right)$ & 5632 & 2727 & 2009 & 1180 & 524 \\
\hline Height 3 & $\mathrm{U}(\mathrm{m} / \mathrm{s})$ & 16,38 & 13,47 & 12,38 & 10,78 & 8,81 \\
\hline$Z=50 m$ & $\mathrm{P}\left(\mathrm{W} / \mathrm{m}^{2}\right)$ & 6674 & 3727 & 2864 & 1882 & 1015 \\
\hline$Z=100 m$ & $\mathrm{P}\left(\mathrm{W} / \mathrm{m}^{2}\right)$ & 7865 & 4862 & 3936 & 2806 & 1740 \\
\hline Height 5 & $\mathrm{U}(\mathrm{m} / \mathrm{s})$ & 18,34 & 16,38 & 15,46 & 14,13 & 12,47 \\
\hline$Z=200 \mathrm{~m}$ & $\mathrm{P}\left(\mathrm{W} / \mathrm{m}^{2}\right)$ & 9311 & 6315 & 5275 & 4011 & 2750 \\
\hline
\end{tabular}

In this table, the wind energy densities are high for the $0.000 \mathrm{~m}$ class because the wind can flow through it without facing any obstacle.

\section{Wind Rose}

A compass rose is a first level of representation of a site: you can display the intensity of attendance, the direction or both simultaneously. It is very practical to have a first estimate of the location of the machines if or two wind directions are preferred [13]. Observation and analysis of the compass rose indicate that: - In Ndjamena: There is predominance of the wind in the northeast direction. The highest is recorded in sector 2. This annual report makes it possible to opt for the North-East, more precisely an inclination with respect to the North of a geometric angle varying between the first and the fourth sector (between 15 and 75) with a preference for sector 2 between (between 15 and 45) where the winds are dominant.

- In Faya: Wind use is highest in sectors 2 and 3, so it is

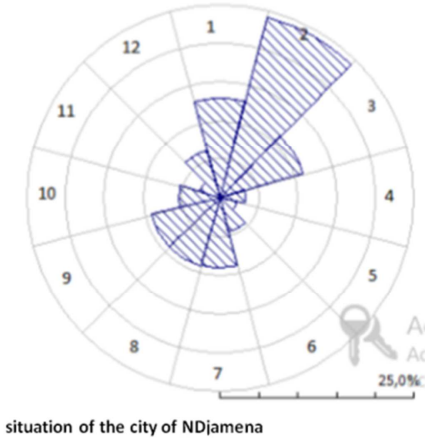

evident that it is this sector that can be the largest contributor to energy production. When installing wind turbines, the orientation should be in the North East direction.

Turbulence analysis

The average variations over the year are sometimes used to define the wind or winds (sometimes quite different) which regularly visit the site [14]. This measurement also makes it possible to see, depending on what one wishes to do with the production of electricity, and with other forms of electricity production of wind turbines, this production is, on average, in phase or in phase with the consumers of electricity, and with other forms of electricity production. One could partly explain these variations by the change in roughness due to the alternation of the seasons. The study of the monthly variations makes it possible to know if there will be a continuity of service (permanent electricity production) at the level of the station. This variation of the wind speed shows two (2) peaks in March and June the site from N'Djamena; April and July for the Faya site. These months are expected to be the most productive in terms of energy.

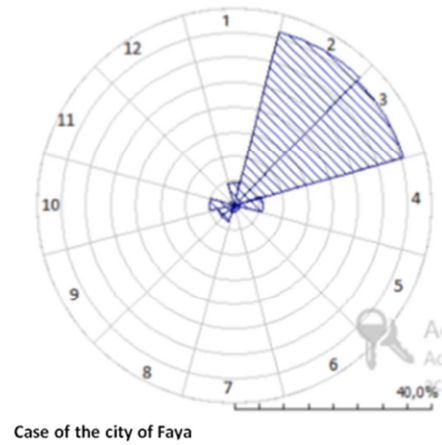

Figure 5. Wind rose at $10 \mathrm{~m}$ for the representation of wind distributions in direction by sector of $30 \mathrm{~s}$. 


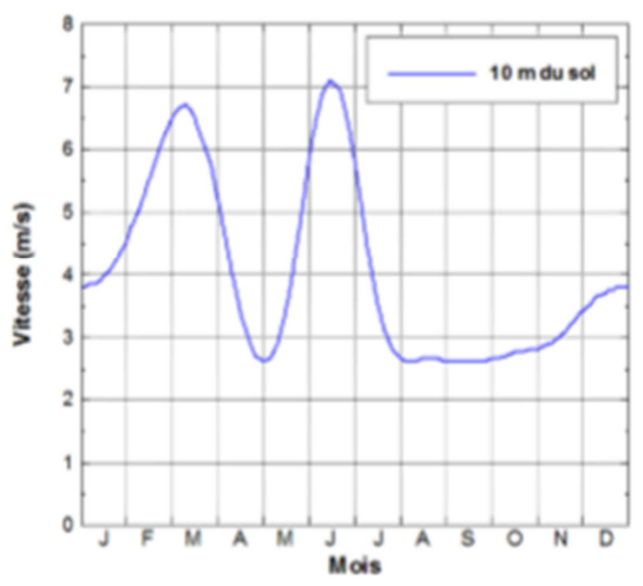

speed according to months in Ndjamena

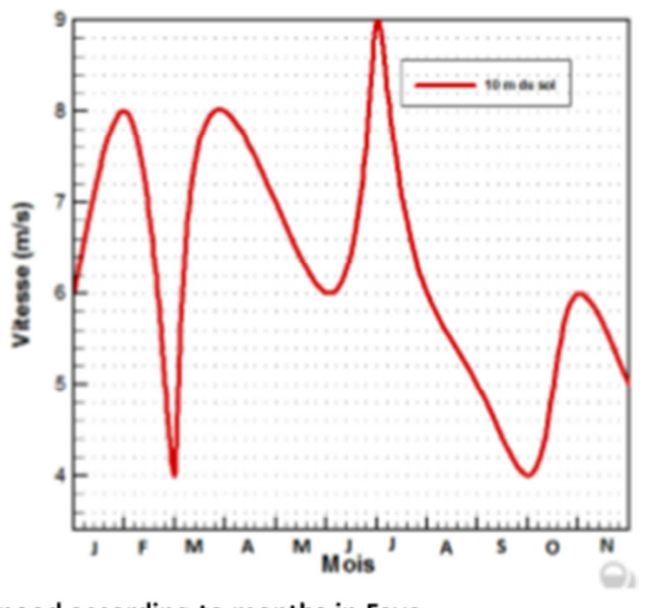

speed according to months in Faya

Figure 6. Average variations in speed over the year.

\section{Data Input Files}

To map the resource, a number of input files had to be prepared:

1. A file describing the site's wind regime;

2. A file of obstacles surrounding the measurement site;

3. A file providing information on the topography of the land (effect of roughness).

a) Wind regime the revenue regimen file obtained after processing the wind measures (date, time and direction) collected on the site. The preparation of this file was done with
Climate Analyst, which is a satellite application of WasP [15].

b) Obstacles The models of the Wind Atlas make it possible to correct the influence that obstacles can have on the measurements carried out on a given site.

c) Topographic maps developed the topographic maps that we have developed using SRTM data mainly contain information on the relief of our sites [16]. The topography is indicated by contour lines. Contour lines section the relief by equidistant horizontal planes which are then projected onto a plane. The vertical distance between 2 planes de fines the equidistance of the curves.

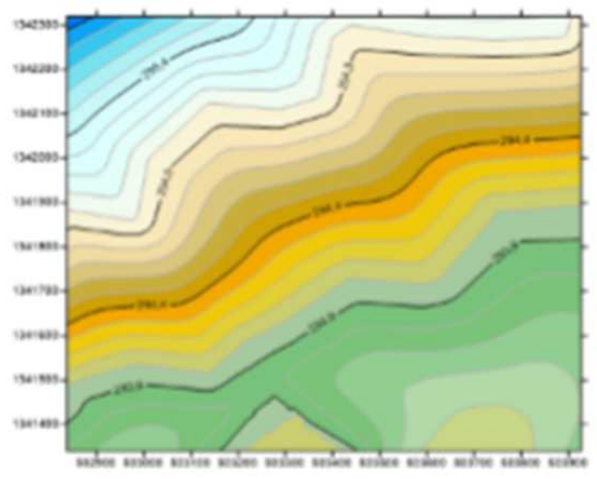

2D Ndjamena (m)

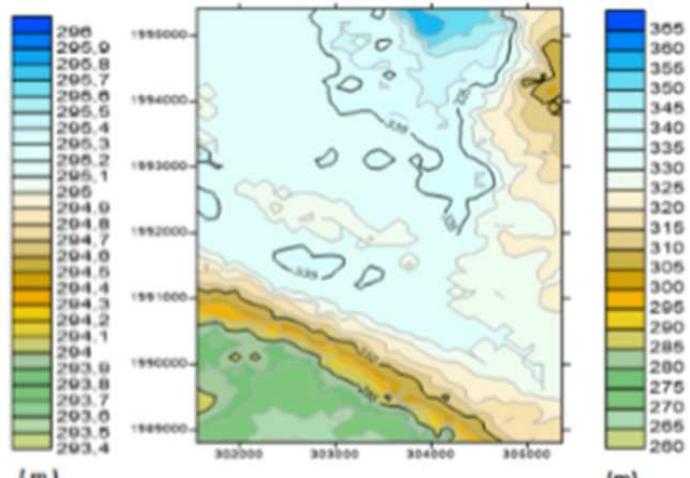

2D Faya

Figure 7. 2D topographic map.

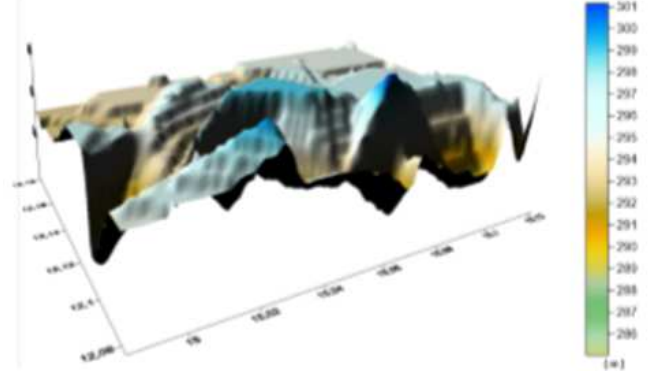

3D N'Djamena

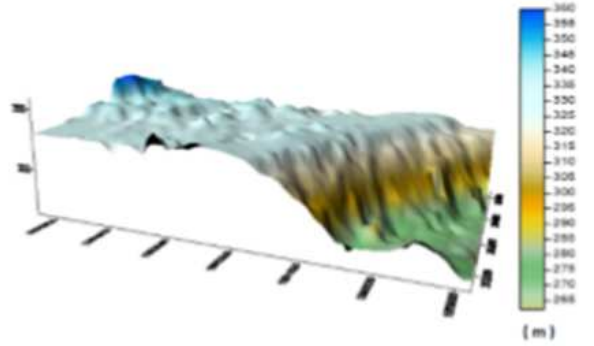

3D Faya

Figure 8. 3D topographic map. 
d) Average energy density

The mapping of the energy density available $100 \mathrm{~m}$ from the ground after vertical extrapolation of the wind speed by the so-called variable coefficient power law is given in the following Figure. The result is obtained after the treatment of all two sites.

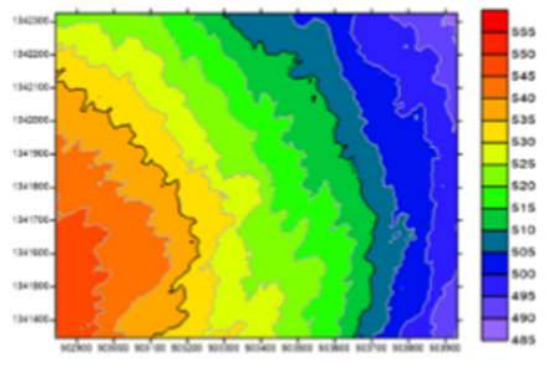

2D N'Djamena

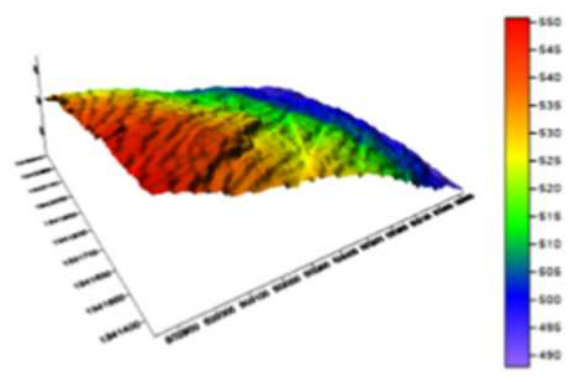

2D Faya

Figure 9. Annual map of the average energy density at $100 \mathrm{~m}$ from the ground $\left(\mathrm{kWh} / \mathrm{m}^{2}\right)$ in $2 \mathrm{D}$

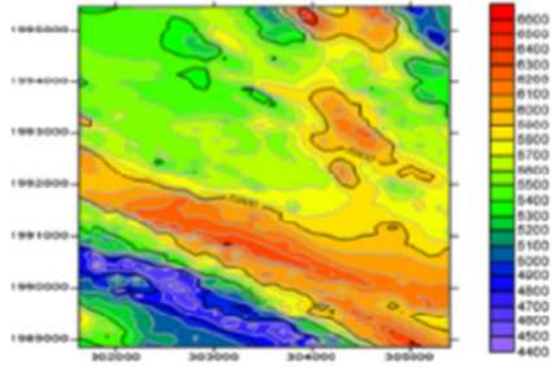

3D N'Djamena

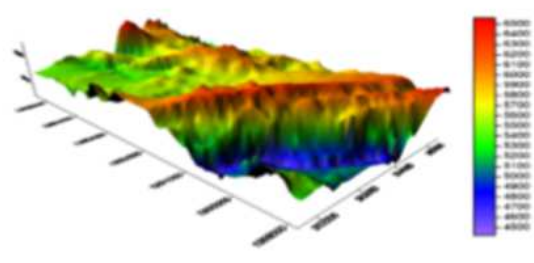

3D Faya

Figure 10. Annual map of the average energy density at $100 \mathrm{~m}$ from the ground $\left(\mathrm{kWh} / \mathrm{m}^{2}\right)$ in $3 D$.

d) Annual wind map in the city of N'Djamena and Faya

The advantage of resource mapping lies in being able to determine how the speed is distributed on the site according to its topography. This representation of the speed distribution makes it possible to select the most suitable sites that can accommodate a wind project. The extrapolation of the speed was made to $100 \mathrm{~m}$ [17]. We notice in this topographic map three dominant colors: - The blue zone, which represents the zone with the lowest wind potential with an average speed of $6.95 \mathrm{~m} / \mathrm{s}$ for the city of N'Djamena and $15 \mathrm{~m} / \mathrm{s}$ for the city of Faya. - The green zone represents the average speed zone; - The red zone represents the zone with the highest wind potential following the North-East direction according to the wind speed with a speed of $7.12 \mathrm{~m} / \mathrm{s}$ following the North-East direction for the city of N'Djamena and $16.4 \mathrm{~m} / \mathrm{s}$ following the North-North-East direction for the city of Faya [18].

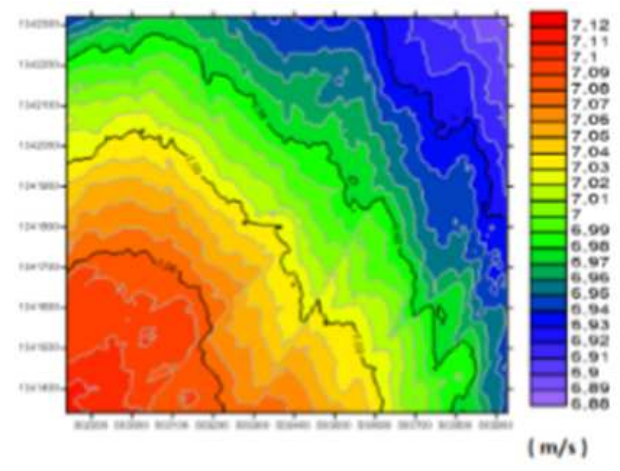

2D N'Djamena

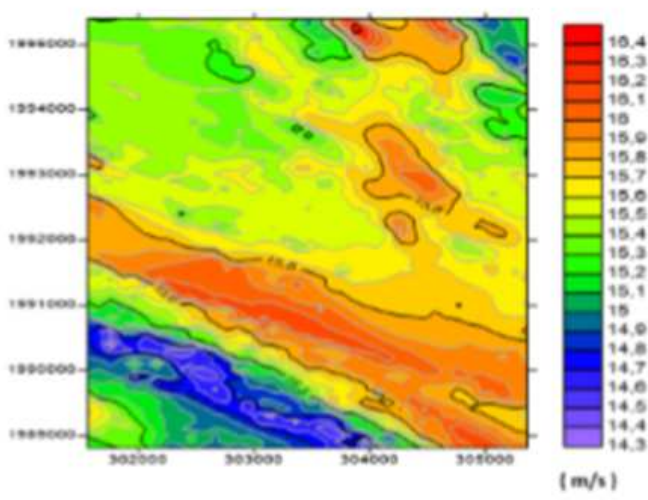

2D Faya

Figure 11. Carte annuelle de la vitesse en 2D. 

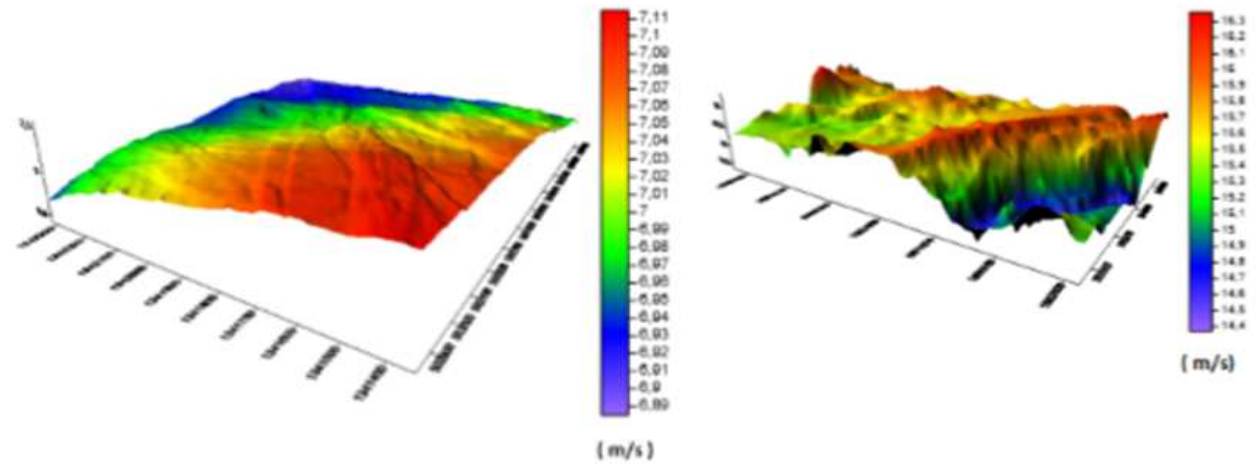

3D N'Djamena

3D Faya

Figure 12. Carte annuelle de la vitesse en $3 D$.

\section{Conclusion}

Estimation of the wind power source of a site is essential before any installation. Depending on the production objective sought, it allows us to judge the advisability of implementing a wind project. In this perspective, we have undertaken to estimate the Jaya wind resource, two sites in the Chad and $\mathrm{N}$ at the $\mathrm{N}$ wind farm. To achieve this, we collected and processed wind data on the various sites considered. The analysis allows the production of annual climate statistics at the level of the stations [19]. It emerges in particular that in N'Djamena, the wind has the mean speed and energy density at $10 \mathrm{~m}$ from the ground, $3.8 \mathrm{~m} / \mathrm{s}$ and $99 \mathrm{~W} / \mathrm{m}^{2}$ respectively. In Faya, on the other hand, we have $5.54 \mathrm{~m} / \mathrm{s}$ and $246 \mathrm{~W} / \mathrm{m}^{2}$ respectively. These statistics clearly showed that the Faya site o ers the greatest wind potential. Modeling, as a means of estimating wind potential for sites for which wind measurements are not available, has been established. The Weibull distribution which is commonly used for this purpose, was considered for our study. Despite the recommendations of Takle and Brown [21], then Salami et al., the wind [22] potential of sites with a high calm rate can be evaluated using Weibull distribution. Thus, the validation of the Weibull distribution through our on-site measurements, allowed that we could logically use the WAsP code for the development of the mapping of the wind resource. To this end, we drew up an inventory of the winds at the two sites considered, then made an inventory of the factors in fl nuancing the resource, such as topography, roughness and obstacles. The mapping of the wind resource that we carried out consists of a distribution of the wind speed according to the relief. The selection of a few highresource areas showed that this mapping is an important decision-making tool that can be used to identify suitable locations for the implementation of wind projects.

\section{References}

[1] ASECNA, «Archives data of the weather station of Tchad», Consulté le 15 juillet 2015 sur le site www.asecna.aero.2005.
[2] Li, M, Li, X., MEP-type distribution function: a better alternative to Weibull function for Wind speed distributions. Renewable Energy 30, 1221-1240. 2005.

[3] Omer, A. M., On the Wind energy resources of Sudan. Renewable and Sustainable Energy Reviews 12, 2117-2139, 2008.

[4] Mathew S, Pandey KP, Modelling the integrated output of wind-driven roto-dynamic pumps. Renew Energy 28: 11431155. 2008

[5] Observ'ER, EDF, 'La Production d'Electricité d'Origine Renouvelables dans le Monde', Observatoire des Energies Renouvelables, $14^{\text {eme }}$ inventaire, Edition 2012. Available from http://www.observ-er.org/observ-er/html/inventaire/Fr/preface asp [Accessed 13 January 2013].

[6] M. Sathyajith and S. P. Geeta, 'Advances in Wind Conversion Springer, Heidelberg, Dordrecht, London, New York, 2011.

[7] H. Faida, J. Saadi, M. Khaider, S. El Alami et M. Monkade, 'Etude et Analyse des Données du Vent en Vue de Dimensionner un Système de Production d'Energie EolienneCas d'un Site au Nord du Maroc', Revue des Energies Renouvelables, Vol. 13, N 3, pp. 477-483, 2010.

[8] J. V. Seguro and T. W. Lambert, 'Modern Estimation of the Parameters of the Weibull Wind Speed Distribution for Wind Energy Analysis', Journal of Wind Energy Engineering and Industrial Aerodynamics, Vol. 85, N 1, pp. 75-84, 2000.

[9] C. Dubois, 'Le Guide de l'Eolien, Techniques et Pratiques', Editions Eyrolles, Paris, 2009.

[10] H. W. Tieleman, 'Roughness Estimation for Wind-Load Simulation Experiments', Journal of Wind Energy Engineering and Industrial Aerodynamics, Vol. 91, N 9, pp. 1163-1173, 2003

[11] H. Lettau, 'Note on Aerodynamic Roughness - Parameter Estimation on the Basis of Roughness - Element Description', Journal of Applied Meteorology, Vol. 8, N 5, pp. 828 -832, 1969.

[12] L. Meishen and L. Xianguo, 'MEP-Type Distribution Function: A Better Alternative to Weibull Function for Wind Speed Distributions', Renewable Energy, Vol. 30, N 8, pp. 1221-1240, 2005.

[13] M. Jamil, S. Parsa and M. Majidi, 'Wind Power Statistics and Evaluation of Wind Energy Density', Renewable Energy, Vol. 6, N 5-6, pp. 623 - 628, 1995. 
[14] Boudia S. M, Benmansour A, Ghellai N, Benmedjahed M, Temporal assessment of wind energy resource at four locations in Algerian Sahara. Energy Conversion and Management 76: 654-664. 2013.

[15] Ohunakin OS, Akinnawonu OO, Assessment of wind energy potential and the economics of wind power generation in Jos, Plateau State, Nigeria. 2012.

[16] Energy Sustain Develop 16: 78-83. Justus CG, Mikhail A, Height variation of wind speed and wind distributions statistics. Geophys Res Lett 3: 261-264, 1976.

[17] C. Ilkılıç, H. Aydın and R. Behçet, 'The Current Status of Wind Energy in Turkey and in the World', Energy Policy, Vol 39, N 2, pp. 961-967, 2011.

[18] A. W. Dahmouni, M. Ben Salah, F. Askri, C. Kerkeni and S. Ben Nasrallah, 'Assessment of Wind Energy Potential and Optimal Electricity Generation in Borj-Cedria, Tunisia', Renewable and Sustainable Energy Reviews, Vol. 15, N 1, pp. 815-820, 2011.
[19] Prem Kumar Chaurasiya, V Kranthi Kumar, Vilas Warudkar \& Siraj Ahmed. Evaluation of Wind Energy Potential and Estimation of Wind Turbine Characteristics for Two Different Sites. International Journal of Ambient Energy. April 2019.

[20] A. Nsengiyumva. Impact d'électrification des zones rurales, par des systèmes photovoltaïques autonomes, sur l'économie Burundaise. Revue des Energies Renouvelables Vol. 20 N 3 p471-482. 2017.

[21] Justus R., « Methods for Estimating Wind Speed Frequency Distributions ", Journal of Applied Meteorology, vol. 17, pp. 350-353, 1978 .

[22] Furkan DINCER., «The analysis on wind energy electricity generation status, potential and policies in the world», In: Renewable and sustainable Energy Reviews, vol. 15, p. 5135$5142,2011$.

[23] Marc RAPIN et Jean-Marc NOEL, «Energie eolienne: Etudeprincipe de cas», Paris: Dunod, 2010.304 p, 2010. 